\title{
Rice, beans and trade crops on the early maritime Silk Route in Southeast Asia
}

Cristina Cobo Castillo ${ }^{1, *}$, Bérénice Bellina ${ }^{2} \&$ Dorian Q Fuller ${ }^{1}$

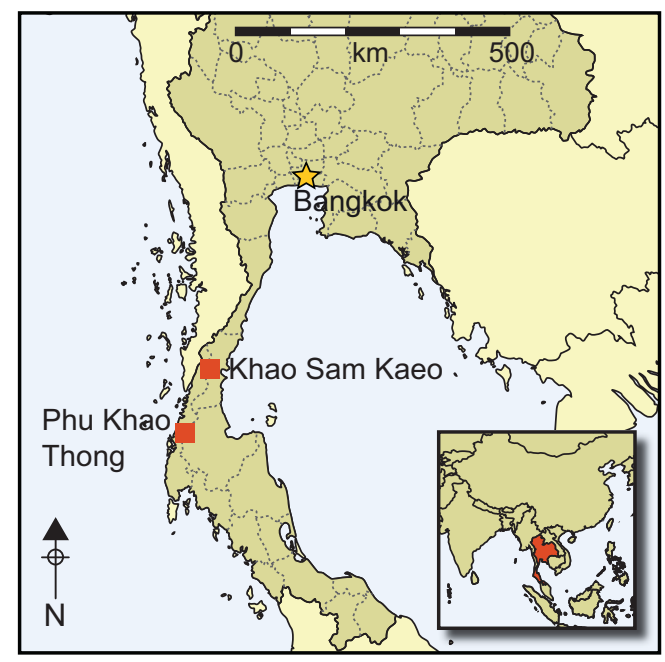

Plant macrofossils from the sites of Khao Sam Kaeo and Phu Khao Thong on the Thai-Malay Peninsula show evidence of crosscultural interactions, particularly between India to the west and Southeast Asia to the east. Archaeobotanical analysis of various cereals, beans and other crops from these assemblages sheds light on the spread and adoption of these species for local agriculture. There is also early evidence for the trade of key commodities such as cotton. The plant remains illustrate a variety of influences and networks of contact across South and Southeast Asia during the late first millennium $B C$.

Keywords: Southeast Asia, Silk Route, first millennium BC, archaeobotany, cereals, pulses, entrepôt, trade

\section{Introduction}

Exchange routes and coastal sites that form part of a trade network have been the subject of much academic scholarship, especially those pertaining to the Indo-Roman trade (Miller 1969; Tomber 2008; van der Veen 2011). People moving along early exchange routes required areas for rest, nourishment, safe harbour, boat repairs and victualling. Regional entrepôts (trading centres) in the ancient world were central to the consolidation and redistribution of goods (Miller 1969; Tomber 2008). Entrepôts were also important for cultural exchange, bringing people of diverse backgrounds together and providing a context

1 Institute of Archaeology, University College London, 31-34 Gordon Square, London WC1H OPY, UK

2 National Centre for Scientific Research (CNRS), UMR 7055 'Préhistoire et Technologie' Maison Archéologie et Ethnologie, 21, allée de l'Université, F-92023 Nanterre, France

* Author for correspondence (Email: cristina.castillo@ucl.ac.uk)

(C) Antiquity Publications Ltd, 2016. This is an Open Access article, distributed under the terms of the Creative Commons Attribution licence (http://creativecommons.org/licenses/by/4.0/), which permits unrestricted re-use, distribution, and reproduction in any medium, provided the original work is properly cited. 


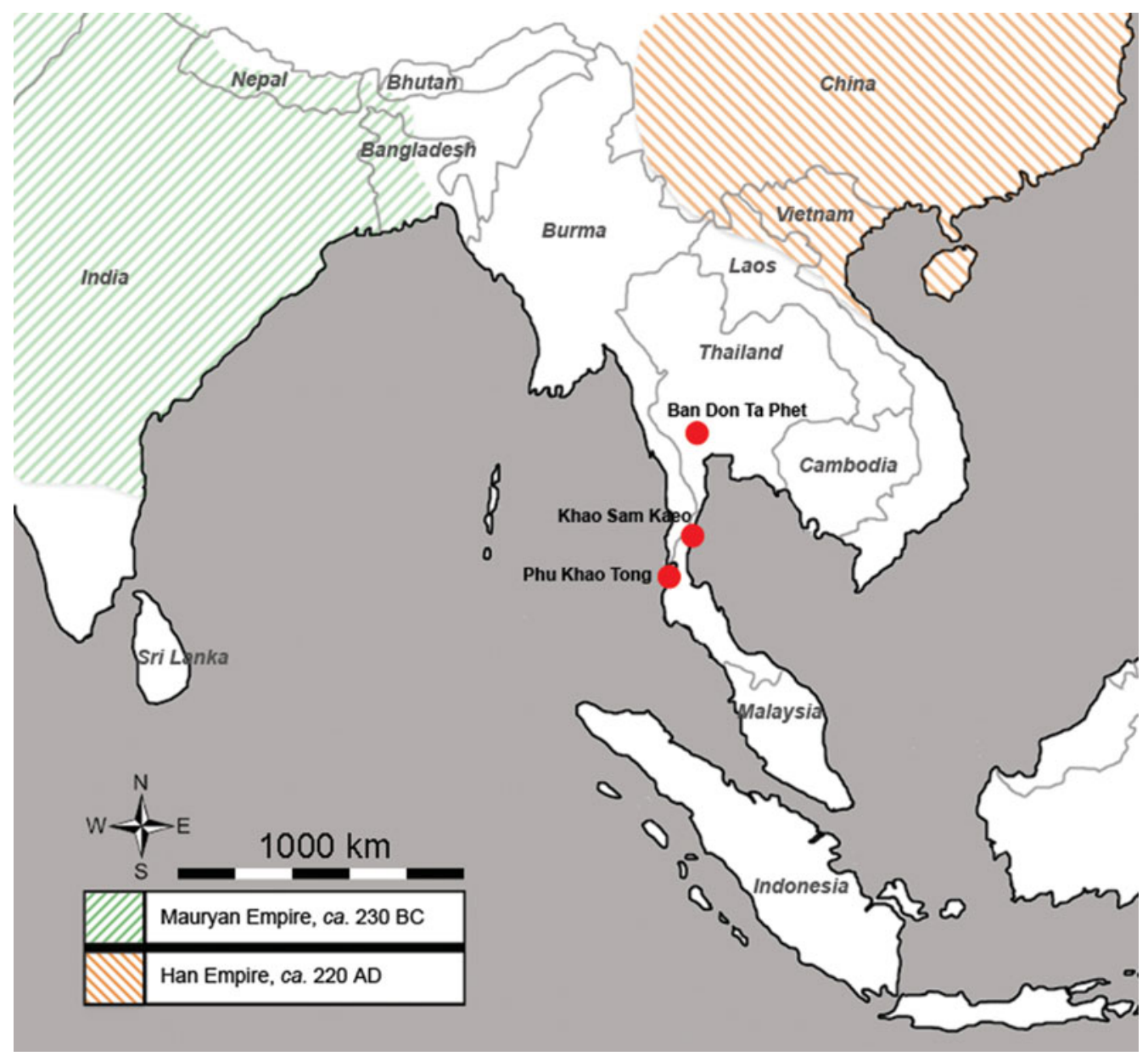

Figure 1. Map showing the archaeological sites mentioned in the text, and the extent of the Han and Mauryan Empires c. third century $B C$.

for the transfer of knowledge and materials, such as approaches to cooking and ingredients. This paper investigates such exchanges through the archaeobotany of two entrepôt sites in the Thai-Malay Peninsula: Phu Khao Thong and the early urban centre of Khao Sam Kaeo (hereafter PKT and KSK respectively, Figure 1). Both sites date to the later part of the first millennium BC, a period when the Thai-Malay peninsula connected the maritime silk roads linking the Mauryan and Han Empires from the Indian Ocean to the South China Sea; as early as the second century BC, the Thai-Malay Peninsula appears in a Chinese Han text (Ch'ien Han Shu) as an overland route to the Indian Ocean and India (Jacq-Hergoualc'h 2002).

The archaeobotanical study of KSK contributes to our understanding of how an early port of trade identified in the South China Sea, with an active exchange network and specialised craft production, would have supported itself. We found evidence for exchanged foodstuffs (C) Antiquity Publications Ltd, 2016 


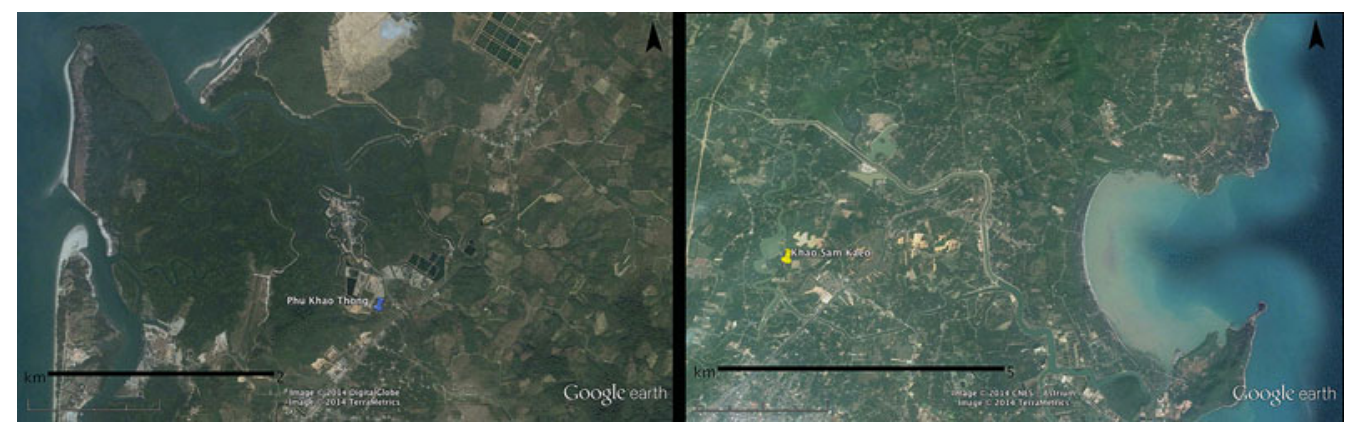

Figure 2. Google Earth images situating the sites KSK and PKT in the surrounding landscape.

and information on the agricultural base that sustained the different communities at KSK, which included the local population, temporary settlers and transient voyagers (Bellina et al. 2014; Bellina in press). The archaeobotany at PKT provides comparative evidence from a contemporaneous site on the Thai-Malay Peninsula, which might have had more direct links with India. PKT and KSK are both strategically located close to the coast, and would have formed a link between the west and east coasts of the peninsula.

\section{Description of the sites, material culture and chronology}

The Metal Age site of Khao Sam Kaeo is located in Chumphon province, $8 \mathrm{~km}$ from the coast $\left(10^{\circ} 31^{\prime}-32^{\prime} \mathrm{N} ; 99^{\circ} 11^{\prime}-12^{\prime} \mathrm{E}\right.$; Figure 2$)$. The site consists of four hills, with a peak elevation averaging $30 \mathrm{~m}$ asl. It is surrounded by lowlands and flanked to the west by the Tha Tapao River. Although an early port city, KSK was not a coastal site, but had access to the sea via the Tha Tapao. Settlements have been found on the plateaus, the slopes of the four hills and on the riverbank. Both domestic and industrial areas have been identified, as well as communal habitation terraces. Several types of structure can be found at the site including terraces, floors, postholes, walls and drainage systems. The site's boundaries are defined by the excavations undertaken across $135(2 \times 2 \mathrm{~m})$ units, and extend to approximately $34 \mathrm{ha}$ in area.

The main settlement period at KSK dates from the fourth to first centuries BC, based on 34 radiocarbon dates (20 of which are AMS) (Table S1 in online supplementary material) and artefact typology. KSK has been identified as the earliest urban settlement in Southeast Asia that was engaged in trans-Asiatic exchange networks (Bellina-Pryce \& Silapanth 2008; Bellina 2014, in press; Bellina et al. 2014). Several communities are represented, and the presence at KSK of craft specialisation in the form of glass working, stone ornament production, metalworking and pottery has been established (Bellina et al. 2014). While some items originated from Indian, Chinese and Southeast Asian locations, others were produced at KSK using transferred technologies. KSK provides data on the beginnings of a long-lasting cultural exchange that linked South Asia and Southeast Asia.

The links between South Asia and East Asia at KSK are well documented. Some artefacts from KSK compare with similar items in South Asia and China (Figure 3), such as rouletted

(C) Antiquity Publications Ltd, 2016 

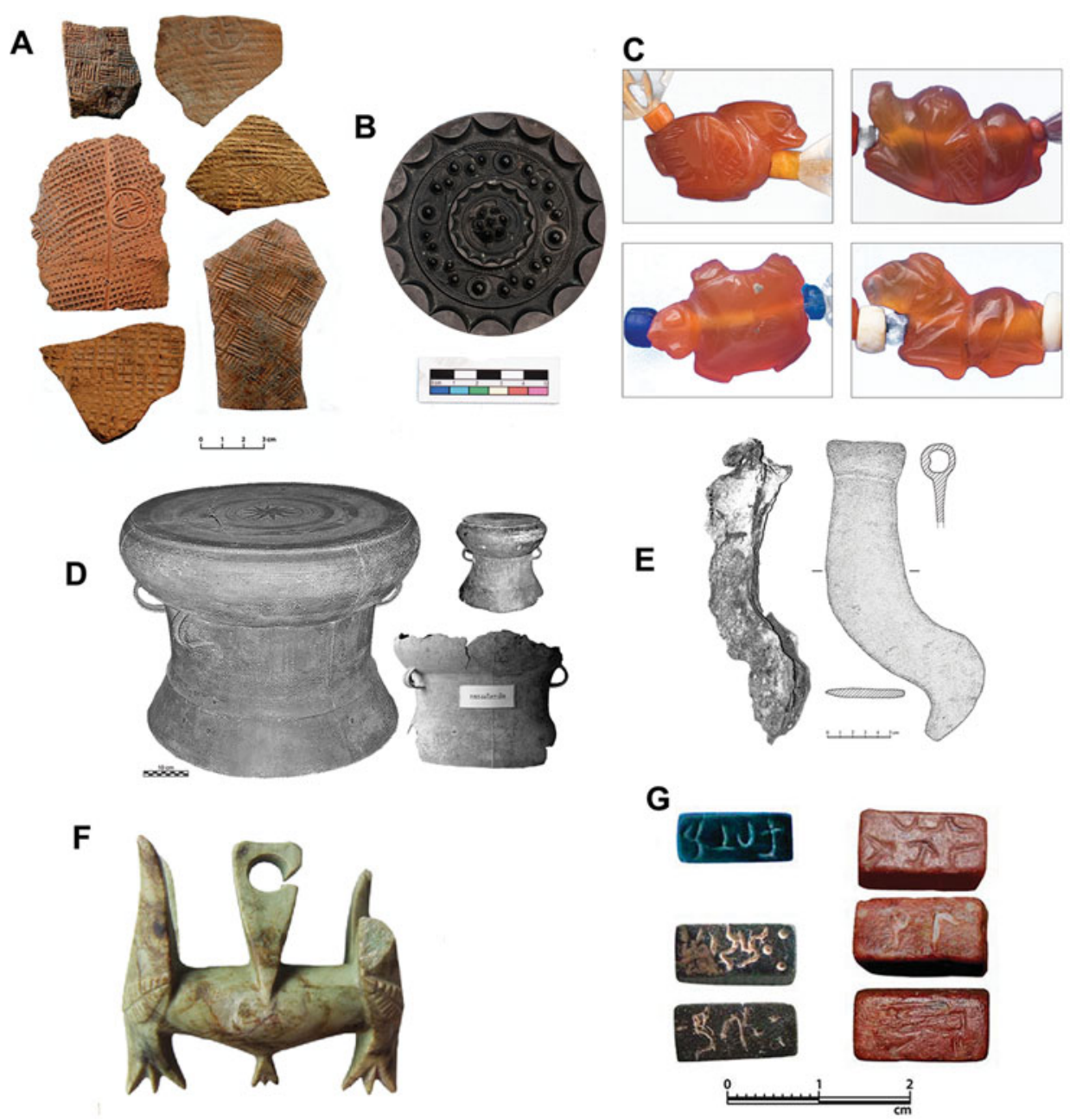

Figure 3. Artefacts from KSK: A) Han sherds; B) Han mirror; C) carnelian artefacts in the form of auspicious symbols; D) Dong Son drum; E) iron-socketed billhook; F) bicephalous earring; G) seals with Indian Brahmi script.

ware, seals inscribed with Brahmi script and carnelian artefacts in the form of auspicious symbols from India, and stamped/impressed ceramics and mirrors from Han China. KSK also forms part of a network with other Southeast Asian sites, as seen by artefacts such as Dong Son drums, semi-precious beads, iron-socketed billhooks, glass beads, glass bracelets and raw material such as nephrite blocks (Lankton et al. 2006; Pryce et al. 2006; Calo 2009; Glover \& Bellina 2011; Bellina et al. 2014; Bellina in press).

Phu Khao Thong (PKT) is a small hill also located in the Kra Isthmus but on the western coast of the peninsula $\left(9^{\circ} 22^{\prime} 49^{\prime \prime} \mathrm{N} ; 98^{\circ} 25^{\prime} 19^{\prime \prime} \mathrm{E}\right.$; Figure 2). It is located $2.8 \mathrm{~km}$ from the Andaman Coast and $152 \mathrm{~km}$ from KSK, as the crow flies. In Thai, the name 'Phu Khao Thong' translates to 'gold hill', referring to the many gold artefacts that were found there. PKT was the first point of entry for ships from South Asia, and, as with KSK, it was an (C) Antiquity Publications Ltd, 2016 
entrepôt, albeit smaller. So while there is some evidence of postholes at PKT, signifying that there was indeed an occupation, it was not an urban settlement, but rather part of a trading complex situated in a bay and protected from the open sea by small islands (Bellina et al. 2014).

PKT's chronology overlaps with that of KSK, although it remained active throughout the early centuries AD. The chronology at PKT is based on four AMS radiocarbon dates, from 200 BC-AD 20 (Table S2), as well as the largest corpus of Indian rouletted ware so far known in Southeast Asia (300-1 BC). Pottery inscribed with Tamil-Brahmi script has been dated to the second century $A D$, and another in Brahmi script is from the fourth century AD (Chaisuwan 2011).

\section{The resource base}

Plant remains at both sites were recovered using the bucket wash-over flotation method with $250 \mu \mathrm{m}$ mesh bags. The samples were sorted and identified at the UCL's Institute of Archaeology down to $0.5 \mathrm{~mm}$ using a low-powered microscope. The analysed plant macroremains came from contexts pertaining to habitation structures, platforms, craft production areas and middens from nearby occupation areas (Castillo 2013). The plant macroremains identified so far have yielded five domesticated crops at KSK and seven at PKT (Table 1; Figure 4). The three cereals identified were domesticated in three distinct centres of origin: rice (Oryza sativa ssp. japonica) in the Yangtze Basin in China, foxtail millet (Setaria italica) in northern China and finger millet (Eleusine cf. coracana) from East Africa. Numerous pulses were found, mostly of Indian origin (Vigna radiata, Vigna mungo, Macrotyloma uniflorum). The rice bean (Vigna cf. umbellata) of Southeast Asian origin was identified at KSK and PKT for the first time in an archaeological context. Another Southeast Asian domesticate, the pomelo (Citrus cf. maxima) was also identified for the first time, at both sites, providing evidence for arboriculture. Some evidence of 'cash' crops or traded plant products included cotton (Gossypium cf. arboreum) and sesame (Sesamum indicum), neither of which are native to southern Thailand.

At both sites, a large component of the dataset came from wild/weed species. Often weed flora is used by archaeobotanists to define systems of land use and cultivation practices (e.g. Bogaard et al. 1999; Fuller \& Qin 2009). To investigate the type of cultivation systems in place, modern agricultural fields have been examined for weeds that occur with crops. Based on modern evidence for rice weed ecology (e.g. Soerjani et al. 1987; Galinato et al. 1999; Weisskopf et al. 2014), the weeds at KSK and PKT indicate rain-fed or dry rice systems.

\section{Subsistence regime and farming}

At KSK and PKT, the ubiquity of a few taxa indicates low diversity and a focus on the cultivation or consumption of only a small number of species. Rice was the main cereal at both sites, and was probably cultivated in nearby hinterlands. In addition to being the most important cereal there today, it also forms a significant part of the overall assemblage in KSK and PKT, occurring in $51 \%$ and $82 \%$ of samples respectively. Based on morphometric and genetic analyses, the rice found at both sites was identified as the Chinese domesticate $O$. 
Table 1. Seed crops identified at Khao Sam Kaeo and Phu Khao Thong, the regions of their origin, and dates of domestication and references on origins of species.

\begin{tabular}{|c|c|c|c|c|}
\hline Taxa & Common name & $\begin{array}{l}\text { Domestic centre of } \\
\text { origin }\end{array}$ & $\begin{array}{l}\text { Date of } \\
\text { domestication }\end{array}$ & Reference \\
\hline \multicolumn{5}{|l|}{ Cereals } \\
\hline $\begin{array}{l}\text { Eleusine } \\
\text { coracana }\end{array}$ & finger millet & $\begin{array}{l}\text { western Uganda to } \\
\text { the Ethiopian } \\
\text { highlands }\end{array}$ & $\begin{array}{l}\text { transferred to India } \\
\text { before } 1000 \mathrm{BC}\end{array}$ & $\begin{array}{l}\text { Giblin \& Fuller } \\
2011\end{array}$ \\
\hline $\begin{array}{l}\text { Oryza sativa } \\
\text { japonica }\end{array}$ & rice & $\begin{array}{l}\text { China (Yangtze } \\
\text { Basin) }\end{array}$ & $5000-4000 \mathrm{BC}$ & $\begin{array}{l}\text { Fuller et al. 2010; } \\
\text { Zhao } 2011\end{array}$ \\
\hline Setaria italica & foxtail millet & northern China & $6000 \mathrm{BC}$ & $\begin{array}{l}\text { d'Ennequin et al. } \\
\text { 2000; Zhao } 2011 \\
\end{array}$ \\
\hline \multicolumn{5}{|l|}{ Pulses } \\
\hline $\begin{array}{l}\text { Cajanus sp. (if } \\
\text { Cajanus cajan) }\end{array}$ & $\begin{array}{l}\text { pigeon pea/red } \\
\text { gram }\end{array}$ & $\begin{array}{l}\text { South Asia: eastern } \\
\text { India/Orissa }\end{array}$ & by $1400 \mathrm{BC}$ & $\begin{array}{c}\text { Van der Maesen } \\
\text { 1989; Fuller \& } \\
\text { Harvey } 2006\end{array}$ \\
\hline $\begin{array}{l}\text { Lablab } \\
\quad \text { purpureus }\end{array}$ & hyacinth bean & East Africa & $\begin{array}{l}\text { transferred to India } \\
\text { before } 1600 \mathrm{BC}\end{array}$ & $\begin{array}{l}\text { Maass et al. 2005; } \\
\text { Fuller \& Harvey } \\
2006\end{array}$ \\
\hline Lathyrus sativus & grass pea & $\begin{array}{l}\text { south-western Asia } \\
\text { or southern } \\
\text { Balkans }\end{array}$ & $\begin{array}{l}\text { transferred to India } \\
\text { before } 2000 \mathrm{BC}\end{array}$ & $\begin{array}{l}\text { Kislev 1989; Zohary } \\
\quad \text { et al. } 2012\end{array}$ \\
\hline $\begin{array}{c}\text { Macrotyloma } \\
\text { uniflorum }\end{array}$ & horsegram & $\begin{array}{l}\text { South Asia: Indian } \\
\text { peninsula and/or } \\
\text { western India }\end{array}$ & $2600-2000 \mathrm{BC}$ & $\begin{array}{l}\text { Fuller \& Harvey } \\
\quad 2006\end{array}$ \\
\hline Vigna mungo & black gram & $\begin{array}{l}\text { Indian including } \\
\text { Western Ghats }\end{array}$ & $2500-2000 \mathrm{BC}$ & $\begin{array}{l}\text { Tomooka et al. } \\
\text { 2002; Fuller \& } \\
\text { Harvey } 2006\end{array}$ \\
\hline Vigna radiata & $\begin{array}{l}\text { mung bean/ } \\
\text { green gram/ } \\
\text { golden gram }\end{array}$ & $\begin{array}{l}\text { South Asia: Indian } \\
\text { peninsula and/or } \\
\text { north-western } \\
\text { India }\end{array}$ & $2600-2000 \mathrm{BC}$ & $\begin{array}{l}\text { Tomooka et al. } \\
\text { 2002; Fuller \& } \\
\text { Harvey } 2006\end{array}$ \\
\hline Vigna umbellata & rice bean & Southeast Asia & unknown & $\begin{array}{l}\text { Seehalak et al. 2006; } \\
\text { Isemura et al. } \\
2011\end{array}$ \\
\hline \multicolumn{5}{|l|}{ Cash crops } \\
\hline Citrus maxima & pomelo & Southeast Asia & unknown & $\begin{array}{l}\text { Niyodham 1991; } \\
\text { Weisskopf \& } \\
\text { Fuller } 2013\end{array}$ \\
\hline $\begin{array}{l}\text { Gossypium } \\
\text { arboreum (on } \\
\text { geographi- } \\
\text { cal/dating } \\
\text { grounds } \\
\text { mostly } \\
\text { probably } \\
\text { arboreum) }\end{array}$ & tree cotton & $\begin{array}{l}\text { South Asia: Pakistan } \\
\text { (if G. arboreum; } \\
\text { G. herbaceum is of } \\
\text { African origin) }\end{array}$ & $6000-5000 \mathrm{BC}$ & $\begin{array}{l}\text { Fuller 2008; Zohary } \\
\quad \text { et al. } 2012\end{array}$ \\
\hline $\begin{array}{l}\text { Sesamum } \\
\quad \text { indicum }\end{array}$ & sesame & South Asia & $2000 \mathrm{BC}$ & $\begin{array}{l}\text { Bedigian 2004; van } \\
\text { der Veen 2011 }\end{array}$ \\
\hline
\end{tabular}

(C) Antiquity Publications Ltd, 2016 

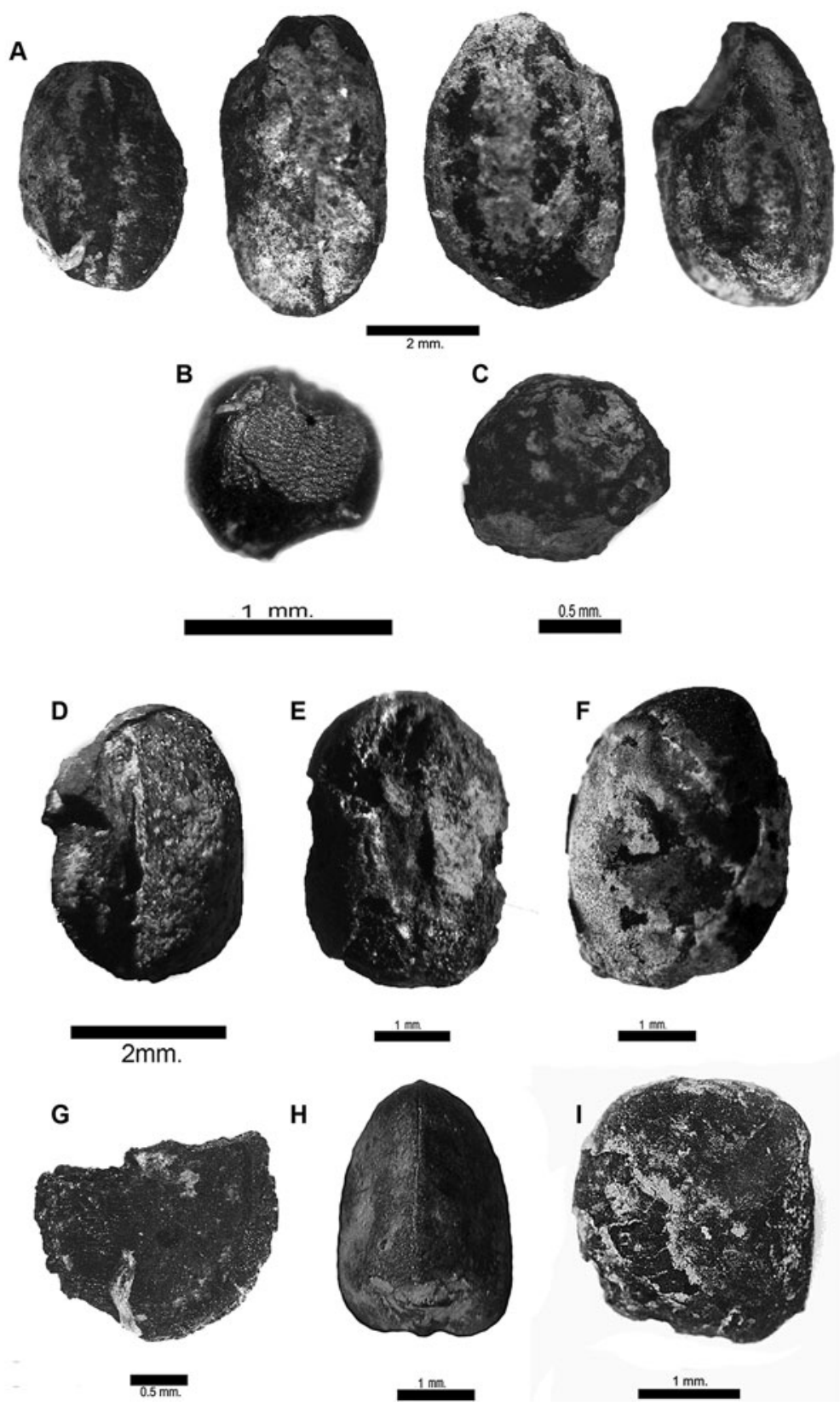

Figure 4. Archaeological cereals and pulses: A) rice caryopses from PKT; B) foxtail millet grain from KSK; C) finger millet from $P K T ; D)$ mung bean from $P K T ; E$ ) black gram from $P K T ; F)$ horsegram from $P K T ; G)$ hyacinth bean from $K S K ; H)$ grass pea from $P K T$; I) pigeon pea from $K S K$. 


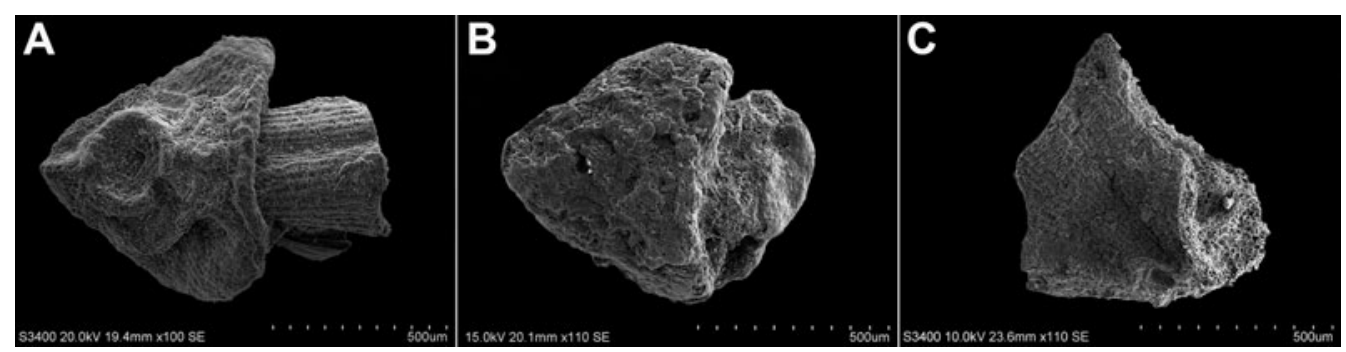

Figure 5. Rice plant parts from KSK: A) domesticated rice spikelet base; B) wild rice spikelet base; C) lemma apiculi.

sativa ssp. japonica (Castillo et al. 2015). While the Indian populations at PKT and KSK could have brought the Indian variety of rice, O. sativa ssp. indica, there was no imperative to do so because rice was already available in Southeast Asia (Castillo 2011). Instead, these immigrant groups might have brought other species not locally available, such as the pulses discussed below.

Rice is represented by several plant parts, including grains, spikelet bases and lemma apiculi (the tip of the rice husk). Spikelet bases can be divided into wild, domesticated and immature forms. At these sites, more than $85 \%$ have the irregular and torn-out scar found in domesticated-type rice (Figure 5A; $\mathrm{n}=1215$ at KSK, and $\mathrm{n}=637$ at PKT).

Lemma apiculi displaying an angled or squared fracture indicate the presence of awned rice. Several lemma apiculi with a squared fracture where the awn would have been attached were found at both sites (Figure $5 \mathrm{C}$ ). Wild rice always has awns, but although awnlessness is a trait of domesticated rice, there are some domesticated rices with awns, especially amongst tropical japonica or javanica rices, such as modern Indonesian bulu. Using domesticated spikelet bases and grain metrics, we infer the presence of an awned variety of tropical japonica. Such forms are typical of dryland and rain-fed systems of cultivation in Southeast Asia (Fuller \& Castillo 2016), and, as already noted, the weed assemblage is dominated by dryland rice weeds. Furthermore, other cultivars found at both sites, such as mung bean (Vigna radiata), are normally grown in dryland cultivation systems. A dry, rain-fed cultivation regime is further confirmed by the geomorphological analysis conducted in KSK by Allen (2009), who suggests that cultivation probably took place on the gently sloping plateau land and hill slopes. Dryland rice cultivation is characterised by a water source derived from rainfall, and by fields without embankments to retain standing water. Modern fields in Southeast Asia demonstrate a suite of weed flora associated with rice cultivation, and have been compared to the weed flora associated with rice at KSK and PKT (Castillo 2013).

While the rice recorded at KSK and PKT was of the japonica subspecies that originated in China, dryland cultivation in Metal Age Thailand was different from the rice cultivation systems found in China during the same period, which were wetland systems, i.e. in fields that could retain standing water (Fuller \& Qin 2009; Weisskopf et al. 2015). From the examination of the archaeobotany of the two Thai sites, it seems probable that wetland rice agriculture was not introduced to the Thai-Malay Peninsula during the last centuries BC. Moreover, the early period of Indian contact did not lead to the translocation of Indian

(C) Antiquity Publications Ltd, 2016 
rices (indica) to Southeast Asia. Indica rice is the dominant species cultivated in modern Thailand, and wetland rice agriculture is practised throughout the region today. Therefore, it is posited that labour-intensive wetland rice agriculture (of indica rice) was introduced after sustained Indian contact in the middle of the first millennium AD, and associated with the development of Indic states in mainland Southeast Asia (Castillo \& Fuller 2010).

\section{Contacts with India}

The material artefacts link India with KSK, either through trade or settled Indian communities of traders, craftspeople and religious men (Bellina et al. 2014). Indian artefacts (i.e. worked stone and glass beads), imports (Indian Fine Paste Ware, raw materials for industries) and foodstuffs may indicate an enclave at KSK. Furthermore, the examination of the pulses and cash crops found at both KSK and PKT contributes to our understanding of trade networks and exchanges with India.

In general, the movements of crops show that people bring with them their preferred, familiar species. In Peninsular Thailand, the Indian community brought a suite of pulses that were formerly unknown in the area, or at least, if present in the wild, undomesticated, such as the mung bean. Mung bean (Vigna radiata), horsegram (Macrotyloma uniflorum) and pigeon pea (Cajanus cajan) were found in both KSK and PKT; but PKT, located on the India-facing coast, had a larger suite of pulses of Indian origin. This included black gram (Vigna mungo) and grass pea (Lathyrus sativus), which were not found at KSK. Grass pea is originally from either the Near East or the Balkans, and came to India before 2000 BC. The grass pea, together with other finds in the Thai-Malay Peninsula such as hyacinth bean (cf. Lablab purpureus) and finger millet (Eleusine coracana), provides evidence of early translocations from as far afield as East Africa and, in the case of the latter two, via India by at least 1600 BC and 1000 BC respectively (Fuller \& Boivin 2009).

While the cultivars found at KSK and PKT demonstrate links with foreign groups, not all new food crops became incorporated in the traditions of Southeast Asian agriculture. The adoption (or lack thereof) of certain foreign crops, may have been affected by social and cultural meanings ascribed to food or culinary versatility. For example, horsegram, domesticated in India in the third millennium BC, was not adopted by the local populations in the Thai-Malay Peninsula in prehistory even though other similar crops were, probably because of culinary versatility and a perception of it as a low-status food. Today, horsegram is considered a poor person's pulse in India (van Wyk 2005), and it does not make good bean sprouts, an important and preferred Southeast Asian way of eating beans nowadays. By contrast, the mung bean plant is very versatile. The seeds can be dried and stored for use at a later date, or they can be germinated and eaten as bean sprouts. The whole plant can also be used as fodder. In South Asia, split mung beans are cooked with spices and made into dhal. In Southeast Asia, they are also used in confectionery, or made into fine noodles (vermicelli). The mung bean is the most important pulse grown in Thailand today, and was introduced to the Thai-Malay Peninsula by at least the second century BC before becoming embedded in regional agricultural traditions. By contrast, horsegram did not take root in Southeast Asia, and was reintroduced experimentally during British colonialism (Burkill 1935). 
As with horsegram, grass pea, found only at PKT, does not seem to have been widely adopted after its initial introduction to the Thai-Malay Peninsula, as it does not form part of the modern Thai diet. This is probably because the grass pea is another poverty food, currently important in areas where food shortages frequently occur, such as central India, Bangladesh, Pakistan, Nepal and Ethiopia (Mahler-Slasky \& Kislev 2010). Grass pea contains a neurotoxic amino acid, which is hard to remove. When grass pea is consumed in great quantities, this toxin causes lathyrism, an irreversible crippling disease (Muehlbauer $\&$ Tullu 1997). Despite these significant disadvantages, it is still eaten routinely by the poor or during famine in India and Ethiopia because it grows well under harsh conditions and in poor soils, although it failed to persist in Southeast Asian traditions.

Other pulses cultivated in present-day Thailand, following their initial introduction from South Asia, include the pigeon pea and the hyacinth bean. Pigeon pea is an important crop grown by the hill tribes in Thailand (Anderson 1993). It thrives on fertile soils and in both humid and drier areas, and it is intercropped with millets, cotton or groundnut. In Laos, upland farmers from many ethnic groups cultivate both pigeon pea and mung bean alongside rice (Roder et al. 1996). So far, the KSK and PKT Cajanus and cf. Cajanus seeds are the earliest found in Southeast Asia, and this crop persisted in regional agriculture. Today, the preference is for fresh pigeon pea seeds and pods eaten as vegetables, although roasted seeds are also eaten (van der Maesen 1989). Likewise, the immature pods of the hyacinth bean are a popular vegetable in Southeast Asia. Other parts of hyacinth bean are also eaten as vegetables - the leaves, young shoots and inflorescences (Shivashankar \& Kulkarni 1989).

\section{Early trade relations}

Trade is best demonstrated at both sites by commodity crops, raw materials and spices, including cotton and sesame (Figure 6). The earliest evidence for cotton in the Old World dates to c. 4500 BC from Mehrgarh in Pakistan (Moulherat et al. 2002), and it then spread through much of India by 1000 BC (Fuller 2008). Although this cannot be verified from charred archaeological remains, this is believed to be South Asian native tree cotton (Gossypium arboreum). The finds from KSK are also probably of this species, although they may have been imported as unprocessed raw material rather than cultivated locally. Earlier evidence of cotton in Southeast Asia comes from the central Thai site Ban Don Ta Phet dating to the fourth century BC, a site that also shows links to India and China in its material culture (Cameron 2010; Glover \& Bellina 2011). Thailand, especially in the very wet south, is not a favourable area for growing cotton because of the unpredictability of rainfall and the lack of cold weather, which would otherwise reduce the impact of pests (Nuttonson 1963). In the early part of the twentieth century, Europeans made several failed attempts to introduce various cotton species to Southeast Asia including the Malay Peninsula (Burkill 1935). It follows that the farmers at KSK or Ban Don Ta Phet may have encountered the same problems. While a thread of cotton found at Ban Don Ta Phet could represent traded textile, the funicular cap (a seed part) recovered from KSK suggests on-site processing of the bolls into fibre, pointing to the importation of raw, unprocessed cotton, probably from India.

(C) Antiquity Publications Ltd, 2016 


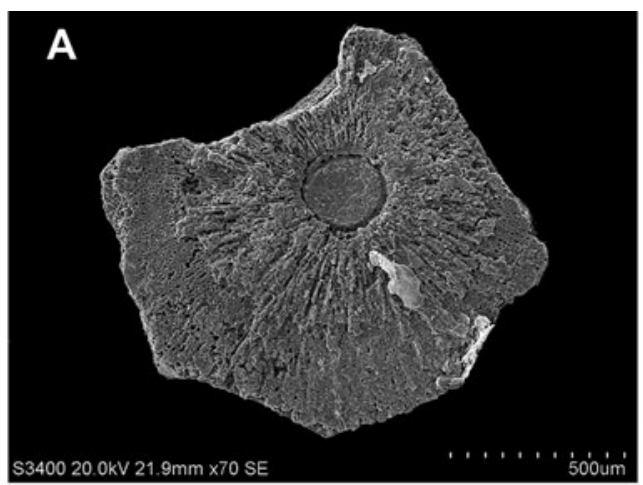

B

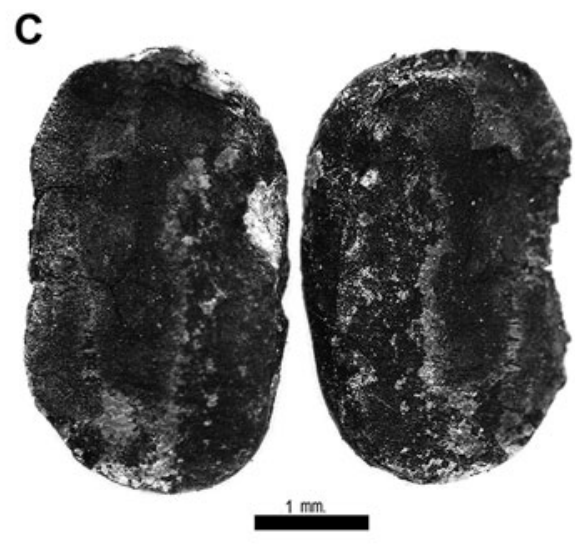

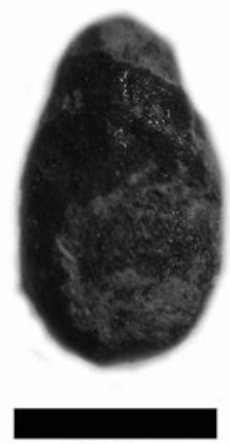

$1 \mathrm{~mm}$.

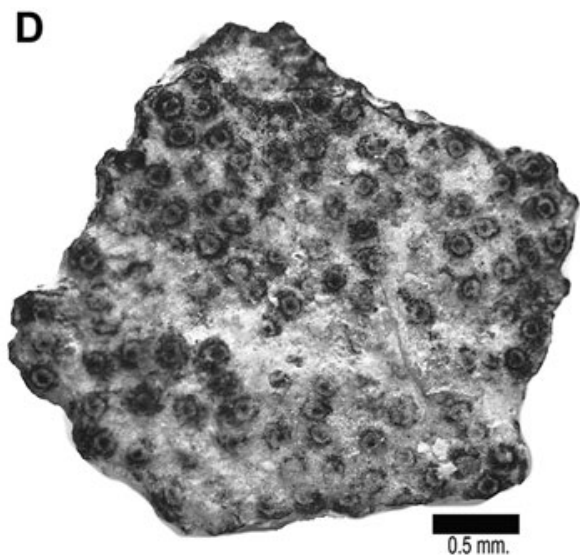

Figure 6. Plant species from KSK and PKT: A) cotton funicular cap from KSK; B) sesame from PKT; C) cotyledons of rice bean from PKT; D) Citrus sp. rind fragment from $K S K$.

Sesame was domesticated in South Asia. While it may have reached Mesopotamia as early as the third millennium BC (Bedigian 2004; van der Veen 2011), the earliest evidence for cultivation comes from the Harappan civilisation areas in Pakistan and adjacent India (Bedigian 2004; Pokharia et al. 2011). A single sesame seed at PKT is, so far, the earliest evidence of sesame appearing to the east of India; it is important as it signals the beginnings of circulation eastwards, prior to its introduction into Han China more than 2000 years ago. A Chinese textual reference (Bencao Gangmu - Standard Inventory of Pharmacology) compiled in the sixteenth century AD mentions the introduction of sesame to China during the Western Han Dynasty (Qiu et al. 2012).

\section{Local crops}

The only foodstuffs found at KSK and PKT that represent indigenous domesticates from Thailand are rice bean and citrus fruit rind, probably from pomelo (Citrus maxima) (Figure 6). Charred rind fragments have been identified as either cf. Citrus or Citrus sp. following favourable comparison with pomelo anatomy (rather than mandarin oranges or citrons). The definite origins of pomelo are still unknown, but Thailand and mainland 
Southeast Asia are generally posited (Weisskopf \& Fuller 2013). The most productive pomelo orchards in modern Thailand are found on riverbanks or former riverbanks (Niyomdham 1991). KSK and PKT fit all the criteria for optimal growing conditions of pomelo, and there is today a commercial pomelo orchard located in valley 2 at KSK. There is evidence from charcoal and historical linguistics for citrons, and probably for some form of orange in southern India at this period, but there is no evidence for an early transmission from Thailand to India of the pomelo (Fuller 2007).

Rice bean is a traditional crop in Southeast and East Asia (Isemura et al. 2011). Genomic studies suggest domestication in northern Thailand, where the wild progenitor Vigna umbellata var. gracilis is found and the greatest genetic diversity occurs (Isemura et al. 2011). Although rice bean is consumed in modern-day India by tribes in the eastern and north-eastern mountainous areas (Arora et al. 1980), it is more important in Burma and farther east. The KSK and PKT finds suggest that rice bean had already been domesticated in northern Thailand prior to the third century BC. Rice bean may have been introduced from northern Thailand, via a northern route (such as through Burma and Bangladesh) to north India. Likewise, rice bean was probably brought from the north of Thailand and cultivated in Peninsular Thailand.

\section{Conclusions}

KSK and PKT became areas of cross-cultural interaction for ideas, technologies and goods due to the influence of, and contact with, South Asia, East Asia and Insular Southeast Asia. The evidence for the trade of ornaments, pottery and metal objects is complemented by that of perishables such as food grains and cotton, which also formed part of the exchange network, and eventually became incorporated into the agricultural diversity of Southeast Asia. From the perspective of food and agriculture, there were strong connections with India, including the probable import of cotton, and perhaps sesame, as well as the introduction of pulses, although apparently not rice of the indica subspecies. All of these pulses might have been grown locally, but only mung bean, pigeon pea and hyacinth bean became part of the long-term agricultural production in Thailand. Also, only certain crops were exported or deemed worthy of adoption abroad, with neither rice bean nor pomelo evidenced in early Indian archaeology despite their cultivation and availability in Thailand during this period. Entrepôts, such as KSK and PKT, brought together different cultural groups with varied dietary traditions and plant products, including cultivable seeds from many regions. In this context, crops may be thought of as having been auditioned for inclusion in the local culinary palette and agro-ecological system, with only a subset passing the test and entering into Southeast Asian agricultural traditions.

\section{Acknowledgements}

Research by Castillo and Fuller on the rice and rice weeds of these sites is supported by a grant from NERC (UK) on 'The impact of evolving of rice systems from China to Southeast Asia' [NE/K003402/1]. PhD research by Castillo was supported by the AHRC. Excavations of KSK and PKT were directed by Bellina and supported by the CNRS and the French Ministry of Foreign Affairs. We would also like to thank Katsunori Tanaka (Hirosaki University) for the aDNA work done on rice from KSK and PKT.

C Antiquity Publications Ltd, 2016 


\section{Supplementary material}

To view supplementary material for this article, please visit http://dx.doi.org/10.15184/aqy. 2016.175

\section{References}

ALLEN, J. 2009. Étude geomorphologique: paleo-drainage, erosion, gestion des sols et agriculture, in B. Bellina (ed.) La campagne 2009 de la mission Franco-Thai en peninsule Thai-Malaise: 20-45. Paris: CNRS.

ANDERSON, E.F. 1993. Plants and people of the Golden Triangle: ethnobotany of the hill tribes of northern Thailand. Portland (OR): Dioscorides.

ARORA, R.K., K.P.S. CHANDEL, B.S. JOSHI \& K.C. PANT. 1980. Rice bean: tribal pulse of eastern India. Economic Botany 34: 260-63. http://dx.doi.org/10.1007/BF02858644

BEDIGIAN, D. 2004. History and lore of sesame in Southwest Asia. Economic Botany 58: 329-53. http://dx.doi.org/10.1663/0013-0001(2004) 058[0330:HALOSI]2.0.CO;2

BellinA, B. 2014. Maritime Silk Roads' ornament industries: socio-political practices and cultural transfers in the South China Sea. Cambridge Archaeological Journal 24: 345-77. http://dx.doi.org/10.1017/S0959774314000547

- 2014. (ed.). In press. Khao Sam Kaeo: an early port-city between the Indian Ocean and the South China Sea. Paris: École française d'Extrême-Orient.

Bellina, B., P. Silapanth, B. Chaisuwan, J. Allen, V. Bernard, B. Borell, P. Bouvet, C. Castillo, L. Dussubieux, J. Malakie, S. Perronnet $\&$ T.O. PRYCE. 2014. The development of coastal polities in the Upper Thai-Malay Peninsula of the late first millennium BCE and the inception of the long-lasting economic and cultural exchange between the East of the Indian Ocean and the South China Sea, in N. Revire \& S. Murphy (ed.) Before Siam was born: 68-89. Bangkok: River.

Bellina-Pryce, B. \& P. Silapanth. 2008. Weaving cultural identities on trans-Asiatic networks: upper Thai-Malay Peninsula_ - an early socio-political landscape. Bulletin de L'École française d'Extrême-Orient 93: 257-93. http://dx.doi.org/10.3406/befeo.2006.6039

Bogatard, A., C. Palmera, G. Jones, M. Charles \& J.G. HodGSON. 1999. A FIBS approach to the use of weed ecology for the archaeobotanical recognition of crop rotation regimes. Journal of Archaeological Science 26: 1211-24. http://dx.doi.org/10.1006/jasc. 1998.0364
BURKILL, I.H. 1935. A dictionary of the economic products of the Malay Peninsula. Kuala Lumpur: Published on behalf of the Governments of Malaysia and Singapore by the Ministry of Agriculture and Co-operatives.

CALÒ, A. 2009. The distribution of bronze drums in early Southeast Asia: trade routes and cultural spheres. Oxford: Archaeopress.

CAmeron, J. 2010. The archaeological textiles from Ban Don Ta Phet in broader perspective, in B. Bellina-Pryce, T.O. Pryce, E. Bacus \& J. Wisseman-Christie (ed.) 50 years of archaeology in Southeast Asia: essays in honour of Ian Glover: 141-52. Bangkok: River.

Castillo, C. 2011. Rice in Thailand: the archaeobotanical contribution. Rice 4: 114-20. http://dx.doi.org/10.1007/s12284-011-9070-2

- 2013. The archaeobotany of Khao Sam Kaeo and Phu Khao Thong: the agriculture of late prehistoric Southern Thailand. Unpublished PhD dissertation, University College London.

Castillo, C. \& D.Q. Fuller. 2010. Still too fragmentary and dependent upon chance? Advances in the study of early Southeast Asian archaeobotany, in B. Bellina-Pryce, T.O. Pryce, E. Bacus \& J. Wisseman-Christie (ed.) 50 years of archaeology in Southeast Asia: essays in honour of Ian Glover: 90-111. Bangkok: River.

Castillo, C., K. Tanaka, Y. Sato, M. Kajale, B. Bellina, C. Higham, N. Chang \& D.Q. FULLER. 2015. Archaeogenetic study of prehistoric rice remains from Thailand and India: evidence of early japonica in South and Southeast Asia. Archaeological and Anthropological Sciences: $1-21$. http://dx.doi.org/10.1007/s12520-015-0236-5

CHAISUWAN, B. 2011. Early contacts between India and the Andaman Coast in Thailand from the second century BCE to eleventh century CE, in P.Y. Manguin, A. Mani \& G. Wade (ed.) Early interactions between South and Southeast Asia: reflections on cross-cultural movements: 83-111. Singapore: Institute of Southeast Asian Studies.

D'Ennequin, M.L.T., O. Panaud, B. Toupance \& A. SARR. 2000. Assessment of genetic relationships between Setaria italica and its wild relative $S$. viridis using AFLP markers. Theoretical and Applied Genetics 100: 1061-66. http://dx.doi.org/10.1007/s001220051387 
FULLER, D.Q. 2007. Non-human genetics, agricultural origins and historical linguistics in South Asia, in M.D. Petraglia \& B. Allchin (ed.) The evolution and history of human populations in South Asia: 393-443. Dordrecht: Springer.

-2008. The spread of textile production and textile crops in India beyond the Harappan zone: an aspect of the emergence of craft specialization and systematic trade, in T. Osada \& A. Uesugi (ed.) Linguistics, archaeology and the human past (Occasional Papers 3): 1-26. Kyoto: Indus Project, Research Institute for Humanity and Nature.

Fuller, D.Q. \& N. Boivin. 2009. Crops, cattle and commensals across the Indian Ocean: current and potential archaeobiological evidence, in G. Lefevre (ed.) Plantes et societés (Études Ocean Indien 42-43): 13-46. Paris: Intitut National des Langues et Civilisations Orientales.

Fuller, D.Q. \& C. Castillo. 2016. Diversification and cultural construction of a crop: the case of glutinous rice and waxy cereals in the food cultures of eastern Asia, in J. Lee-Thorp \& M.A. Katzenberg (ed.) The Oxford handbook of the archaeology of food and diet. Oxford: Oxford University Press. http://dx.doi.org/ 10.1093/oxfordhb/ 9780199694013.013 .8

Fuller, D.Q. \& E.L. Harvey. 2006. The archaeobotany of Indian pulses: identification, processing and evidence for cultivation. Environmental Archaeology 11: 219-46. http://dx.doi.org/10.1179/174963106x123232

Fuller, D.Q. \& L. QIN. 2009. Water management and labour in the origins and dispersal of Asian rice. World Archaeology 41: 88-111. http://dx.doi.org/10.1080/00438240802668321

Fuller, D.Q., Y.-I. Sato, C. Castillo, L. Qin, A.R. WeISSKOPF, E.J. KingWELL-BANHAM, J. Song, S.-M. AHn \& J. van ETten. 2010. Consilience of genetics and archaeobotany in the entangled history of rice. Archaeological and Anthropological Sciences 2: 115-31. http://dx.doi.org/10.1007/s12520-010-0035-y

Galinato, M.I., K. Moody \& C.M. Piggin. 1999. Upland rice weeds of South and Southeast Asia. Makati: International Rice Research Institute.

Giblin, J. \& D.Q. Fuller. 2011. First- and second-millennium AD agriculture in Rwanda: archaeobotanical finds and radiocarbon dates from seven sites. Vegetation History and Archaeobotany 20: 253-65.

Glover, I.C. \& B. Bellina. 2011. Ban Don Ta Phet and Khao Sam Kaeo: the earliest Indian contact reassessed, in P.-Y. Manguin, A. Mani \& G. Wade (ed.) Early interactions between South and Southeast Asia: reflections on cross-cultural movements: 17-45. Singapore: Institute of Southeast Asian Studies.
Isemura, T., N. TOMOOKA, A. KaGA \&

D.A. Vaughan. 2011. Comparison of the pattern of crop domestication between two Asian beans, azuki bean (Vigna angularis) and rice bean (V. umbellata). Japan Agricultural Research Quarterly 45: 23-30. http://dx.doi.org/10.6090/jarq.45.23

JaCQ-HergoualC'H, M. 2002. The Malay Peninsula: crossroads of the maritime Silk Road (100 BC-1300 $A D)$. Leiden: Brill.

KISLEV, M.E. 1989. Origins of the cultivation of Lathyrus sativus and L. cicero (Fabaceae). Economic Botany 43: 262-70. http://dx.doi.org/10.1007/BF02859868

Lankton, J.W., L. Dussubieux \& B. Gratuze. 2006. Glass from Khao Sam Kaeo: transferred technology for an early Southeast Asian exchange network. Bulletin de l'École française d'Extrême-Orient 93: 317-51. http://dx.doi.org/10.3406/befeo.2006.6041

MaAss, B.L., R.H. Jamnadass, J. Hanson \& B.C. Pengelly. 2005. Determining sources of diversity in cultivated and wild Lablab purpureus related to provenance of germplasm by using amplified fragment length polymorphism. Genetic Resources and Crop Evolution 52: 683-95. http://dx.doi.org/10.1007/s10722-003-6019-3

Mahler-Slasky, Y. \& M.E. KISLEV. 2010. Lathyrus consumption in late Bronze and Iron Age sites in Israel: an Aegean affinity. Journal of Archaeological Science 37: 2477-85. http://dx.doi.org/10.1016/j.jas.2010.05.008

MilleR, J.I. 1969. The spice trade of the Roman Empire $29 B C$ to $A D$ 641. Oxford: Clarendon.

Moulherat, C., M. Tengberg, J.-F. Haquet \& B. Mille. 2002. First evidence of cotton at Neolithic Mehrgarh, Pakistan: analysis of mineralized fibres from a copper bead. Journal of Archaeological Science 29: 1393-401. http://dx.doi.org/10.1006/jasc.2001.0779

Muehlbauer, F.J. \& A. Tullu. 1997. Lathyrus sativus L. EcoPort. Available at: http://ecoport.org/ep?Plant=7164\&entityType= $\mathrm{PL} * * *$ \&entityDisplayCategory=full (accessed 15 July 2016).

Niyomdham, C. 1991. Citrus maxima (Burm.) Merr., in R.E. Coronel \& E.W.M. Verheij (ed.) Plant resources of South-east Asia no. 2: edible fruits and nuts: 128-31. Wageningen: Pudoc.

NutTonson, M.Y. 1963. The physical environment and agriculture of Thailand. Washington, D.C.: American Institute of Crop Ecology. 


\section{Rice, beans and trade crops on the early maritime Silk Route in Southeast Asia}

POKHARIA, A.K., J.S. KHARAKWAL, R.S. RAWAT, T. Osada, C.M. Nautiyal \& A. Srivastava. 2011. Archaeobotany and archaeology at Kanmer, a Harappan site in Kachchh, Gujarat: evidence for adaptation in response to climatic variability. Current Science 100: 1833-46.

Pryce, T.O., B. Bellina \& A. Bennett. 2006. The development of metallurgies in the Upper Thai-Malay peninsula: initial interpretation of the archaeometallurgical evidence from Khao Sam Kaeo. Bulletin de l'Ecole française d'Extrême-Orient 93: 295-315.

http://dx.doi.org/10.3406/befeo.2006.6040

QiU, Z., Y. Zhang, D. Bedigian, X. Li, C. Wang \& H. JIANG. 2012. Sesame utilization in China: new archaeobotanical evidence from Xinjiang. Economic Botany 66: 255-63. http://dx.doi.org/10.1007/s12231-012-9204-5

Roder, W., B. Keoboulapha, K. Vannalath \& B. Phouaravanh. 1996. Glutinous rice and its importance for hill farmers in Laos. Economic Botany 50: 401-408. http://dx.doi.org/10.1007/BF02866522

SEehalaK, W., N. TOMOOKa, A. Waranyuwat, P. Thipyapong, P. LaOsuwan, A. Kaga $\&$ D.A. VAughan. 2006. Genetic diversity of the Vigna germplasm from Thailand and neighboring regions revealed by AFLP analysis. Genetic Resources and Crop Evolution 53: 1043-59. http://dx.doi.org/10.1007/s10722-004-7939-2

SHIVASHANKAR, G. \& R.S. KULKARNI. 1989. Lablab purpureus L. (Sweet), in L.J.G. Van der Maesen \& S. Somaatmadja (ed.) Plant resources of South-east Asia no. 1: pulses: 48-50. Wageningen: Pudoc.

SoERJAni, M., A.J.G.H. Kostermans \& G. TJitrosoepomo. 1987. Weeds of rice in Indonesia. Jakarta: Balai Pustaka.

TOMBER, R. 2008. Indo-Roman trade: from pots to pepper. London: Duckworth.
TOMOOKA, N., D.A. Vaughan, H. Moss \& N. MAXTED. 2002. The Asian Vigna: genus Vigna subgenus Ceratotropis genetic resources. New York: Kluwer Academic. http://dx.doi.org/10.1007/978-94-010-0314-8

VAn der Maesen, L.J.G. 1989. Cajanus cajan (L.) Millsp., in L.J.G. van der Maesen \& S. Somaatmadja (ed.) Plant resources of South-east Asia no. 1: pulses: 39-42. Wageningen: Pudoc.

VAN DER VEEN, M. 2011. Consumption, trade and innovation: exploring the botanical remains from the Roman and Islamic ports at Quseir al-Qadim, Egypt. Frankfurt: Magna.

VAN WYK, B.-E. 2005. Food plants of the world. Singapore: Timber.

Weisskopf, A. \& D.Q. Fuller. 2013. Citrus fruits: origins and development, in C. Smith (ed.) Encyclopedia of global archaeology: 1479-83. New York: Springer.

Weisskopf, A., E. Harvey, E. KingWell-Banham, D.Q. Fuller, M. Kajale \& R. Mohanty. 2014. Archaeobotanical implications of phytolith assemblages from cultivated rice systems, wild rice stands and macro-regional patterns. Journal of Archaeological Science 51: 43-53.

http://dx.doi.org/10.1016/j.jas.2013.04.026

Weisskopf, A., L. QIN, J. Ding, P. Ding, G. Sun \& D.Q. Fuller. 2015. Applying phytoliths to the reconstruction of rice agriculture: from wet to dry and back again in the Neolithic Lower Yangtze. Antiquity 89: 1051-63.

http://dx.doi.org/10.15184/aqy.2015.94

ZHAO, Z. 2011. New archaeobotanic data for the study of the origins of agriculture in China. Current Anthropology 52(S4): S295-306. http://dx.doi.org/10.1086/659308

Zohary, D., M. Hopf \& E. WeISs. 2012. Domestication of plants in the Old World: the origin and spread of domesticated plants in south-west Asia, Europe, and the Mediterranean Basin. Oxford: Oxford University Press. http://dx.doi.org/10.1093/acprof: osobl/9780199549061.001.0001

Received: 20 July 2015; Accepted: 23 October 2015; Revised: 25 October 2015 